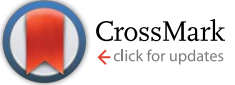

Received 11th November 2016 Accepted 17th January 2017

DOI: 10.1039/c6ra26663k

www.rsc.org/advances
Cite this: RSC Adv., 2017, 7, 7763

\section{Formation mechanism of hafnium oxide nanoparticles by a hydrothermal route}

\begin{abstract}
Yingying Wan and Xingping Zhou*
Hafnium oxide nanoparticles (NPs) were synthesized by a hydrothermal route, using hafnium tetrachloride $\left(\mathrm{HfCl}_{4}\right)$ as the starting material and sodium hydroxide $(\mathrm{NaOH})$ to adjust the $\mathrm{pH}$. Through changing the aging temperature, concentration of $\mathrm{NaOH}$ and reaction time, both pure tetragonal hafnium oxide $\left(\mathrm{t}-\mathrm{HfO}_{2}\right)$ and pure monoclinic hafnium oxide $\left(\mathrm{m}-\mathrm{HfO}_{2}\right)$ were obtained. X-ray diffraction (XRD) spectra and transmission electron microscopy (TEM) images indicated that the shapes of $\mathrm{t}-\mathrm{HfO}_{2} \mathrm{NPs}$ and $\mathrm{m}-\mathrm{HfO}_{2} \mathrm{NPs}$ were nearspherical and spindle-like, respectively. The formation of $\mathrm{t}-\mathrm{HfO}_{2} \mathrm{NPs}$ or $\mathrm{m}-\mathrm{HfO}_{2} \mathrm{NPs}$ is probably related to their crystal cell structure, thermodynamic and kinetic stabilities. Tetragonal $\mathrm{HfO}_{2}$ is produced originally in the process of the formation of monoclinic $\mathrm{HfO}_{2}$. A higher temperature, lower concentration of $\mathrm{NaOH}$, longer reaction time and addition of $\mathrm{m}-\mathrm{HfO}_{2}$ seeds are beneficial for the formation of $\mathrm{m}-\mathrm{HfO}_{2}$ NPs. By analysis and calculation of the equilibrium constants involving hydrolysis of hafnium ions, the changes in the mole fractions of hafnium hydro-complexes with $\mathrm{pH}$ were determined. The $\mathrm{Hf}(\mathrm{OH})_{6}{ }^{2-}$ ion is assigned to the precursory hydro-complex for the formation of $\mathrm{HfO}_{2}$ nanoparticles transformed from $\mathrm{Hf}(\mathrm{OH})_{4}$ gel according to a comparison between the influences of $\mathrm{pH}$ on the equilibrium and the formation of $\mathrm{HfO}_{2}$ particles. Moreover, the formation of $\mathrm{HfO}_{2} \mathrm{NPs}$ was obviously promoted and the size was reduced by addition of seeds, suggesting that the formation of $\mathrm{HfO}_{2} \mathrm{NPs}$ is controlled by the surface-deposition reaction. The above results are of great importance for studying nano-inorganic solution chemistry.
\end{abstract}

\section{Introduction}

Nanostructured materials have a lot of important applications in various fields because of their unique properties. ${ }^{1-3}$ Hafnium is known as the "little brother" of titanium and zirconium. Its dioxide $\left(\mathrm{HfO}_{2}\right)$ is a material with a number of technologically attractive properties such as high melting point $\left(2758^{\circ} \mathrm{C}\right)$, high dielectric constant $(\approx 30)$, high chemical stability, a wide band gap $(>5.0 \mathrm{eV})$, and high neutron absorption cross section. ${ }^{4,5}$ It often plays an important role in the continuous down-scaling of integrated circuits since new insulating materials with a high dielectric constant are being researched to replace $\mathrm{SiO}_{2}$ as a gate dielectric. ${ }^{6,7}$ In terms of structural characteristics, hafnium oxide exists in three polymorphic structures, namely monoclinic $\left(\mathrm{m}-\mathrm{HfO}_{2}\right)$ at low temperature, tetragonal $\left(\mathrm{t}-\mathrm{HfO} \mathrm{O}_{2}\right)$ above $2050 \mathrm{~K}$, and cubic $\left(\mathrm{c}-\mathrm{HfO}_{2}\right)$ at around $2803 \mathrm{~K}^{8-10}$ Each structure has different applications.

The optical, electrical and other properties of $\mathrm{HfO}_{2}$ nanoparticles (NPs) are strongly affected by their size, morphology, and surface characteristics. ${ }^{\mathbf{1 1} 12}$ Therefore, it is necessary to consider the required specifications of $\mathrm{HfO}_{2}$ NPs before

College of Chemistry, Chemical Engineering and Biotechnology, Donghua University, Shanghai 201620, PR China. E-mail: xpzhou@dhu.edu.cn; Fax: +86-21-67792657; Tel: $+86-21-67792657$ choosing the synthesis method. Up to now, researchers have developed some synthesis approaches such as gel-sol method, ${ }^{\mathbf{1 3}}$ microemulsion processes ${ }^{\mathbf{1 4}}$ and precipitation. ${ }^{\mathbf{1 0 , 1 5}}$ However, these methods have some drawbacks, such as complicated operation, low yield and agglomerated products. In addition, all these ways only can obtain the m- $\mathrm{HfO}_{2}$ NPs. Preparation of $\mathrm{t}-\mathrm{HfO}_{2}$ NPs has been rarely reported so far. More importantly, the formation mechanism and crystal form or morphology control of $\mathrm{HfO}_{2}$ NPs are less reported.

Recently, many efforts have been undertaken to improve the synthesis method. As a promising approach, hydrothermal synthesis ${ }^{16-18}$ is widely used to synthesize nanocrystalline oxide materials due to the mild reaction condition, simple operation and no roasting. A. Sahraneshin ${ }^{\mathbf{1 6}}$ synthesized three differently shaped $\mathrm{HfO}_{2}$ NPs via a surfactant-assisted hydrothermal reaction in highly alkaline media. The products obtained were flower-like nanostructures $(20.0 \mathrm{~nm}$ in diameter $)$, polycrystalline nanoagglomerates $(25.0 \mathrm{~nm}$ in diameter), and waterdispersible single nanoparticles $(4.0 \mathrm{~nm}$ in diameter). In addition, S. A. Eliziario ${ }^{8}$ successfully obtained the $\mathrm{HfO}_{2} \mathrm{NPs}$ by the microwave hydrothermal method. The temperature chosen was $140{ }^{\circ} \mathrm{C}$ and these nanostructures exhibited an average width in the range from 15.0 to $75.0 \mathrm{~nm}$ as well as an average height between 85.0 and $105.0 \mathrm{~nm}$. The hydrothermal method allows to control size, morphology and the composition of the 
products, and to obtain homogeneous and dispersed nanoparticles, through varying parameters such as temperature, pressure, duration of the process, concentration and acidity $(\mathrm{pH}){ }^{19-21}$ The control of particle size and morphology is the result of processes of coarsening and redissolution-recrystallization which takes place under conditions of high pressure and temperature. The main advantages of hydrothermal method are simplicity and convenience.

In common, hydrothermal method still needs improvement in terms of yield, monodispersity, structural perfection, and size control. For synthesizing some nanoparticles, seeding is a very effective way to control particle size, to determine the crystal form $^{22}$ and even to study the nucleation and growth mechanisms. Some researchers have made in-depth studies on this technology. Our previous studies reported that the addition of seeds has been able to systematically control the particle morphology and studied the nucleation and growth mechanisms of $\mathrm{ZrO}_{2}$ (ref. 22) and $\mathrm{TiO}_{2} \cdot{ }^{23}$ The seeds inhibit aggregation and the formation of secondary particles, so as to obtain the product wanted. Generally, the surface-deposition of monomers is not often the rate-determining step for the formation of nanoparticles unless the formation is accelerated and the particle size is controlled by seeding. Also, in this case, the sizedistribution of nanoparticles is commonly narrowed.

In this paper, we used a hydrothermal route to prepare hafnium oxide nanoparticles. Effects of temperature, $\mathrm{NaOH}$ concentration, duration and crystal form of seeds were investigated to study the formation mechanisms of $\mathrm{HfO}_{2} \mathrm{NPs}$ from aspects of precursory complexes, thermodynamic and kinetic stabilities.

\section{Experimental}

\section{Materials}

$\mathrm{HfCl}_{4}$ (AR, 99.0\%), sodium hydroxide (AR, 96.0\%), sodium dodecyl-benzenesulfonate (AR, 88.0\%), dodecylamine (CP) were all purchased from Sinopharm Chemical Reagent Co., Ltd.

\section{Synthesis}

Preparation of $\mathbf{H f O}_{2}$ nanoparticles. The $\mathrm{HfO}_{2}$ nanoparticles (NPs) were synthesized by the hydrothermal route. The standard experimental procedure is described as follows. The hafnium hydroxide chloride $\left(\mathrm{Hf}(\mathrm{OH})_{2} \mathrm{Cl}_{2}\right)$ solution was firstly prepared by dissolving $0.160 \mathrm{~g}$ of $\mathrm{HfCl}_{4}$ in $10.0 \mathrm{~mL}$ of de-ionized water. $\mathrm{NaOH}$ aqueous solution $(3.0 \mathrm{M}, 10.0 \mathrm{~mL})$ was added dropwise to the solution above, causing the reaction with $\mathrm{Hf}(\mathrm{OH})_{2} \mathrm{Cl}_{2}$ to form hafnium hydroxide $\left(\mathrm{Hf}(\mathrm{OH})_{4}\right)$. After that, the solution was transferred into a $100 \mathrm{~mL}$ Teflon-lined autoclave with inner diameter of $c a .4 .2 \mathrm{~cm}$, and the sealed autoclave was heated to $120{ }^{\circ} \mathrm{C}$ and maintained for $24 \mathrm{~h}$. The products were purified by centrifugation for three cycles with alcohol and de-ionized water alternately after the autoclave was cooled down. Finally the precipitate was dried at $50{ }^{\circ} \mathrm{C}$ for $24 \mathrm{~h}$. The procedure is summarized in Scheme 1.

Preparation of tetragonal and monoclinic $\mathbf{H f O}_{2}$ seeds. The synthesis procedure of monoclinic $\mathrm{HfO}_{2}\left(\mathrm{~m}-\mathrm{HfO}_{2}\right)$ seeds is

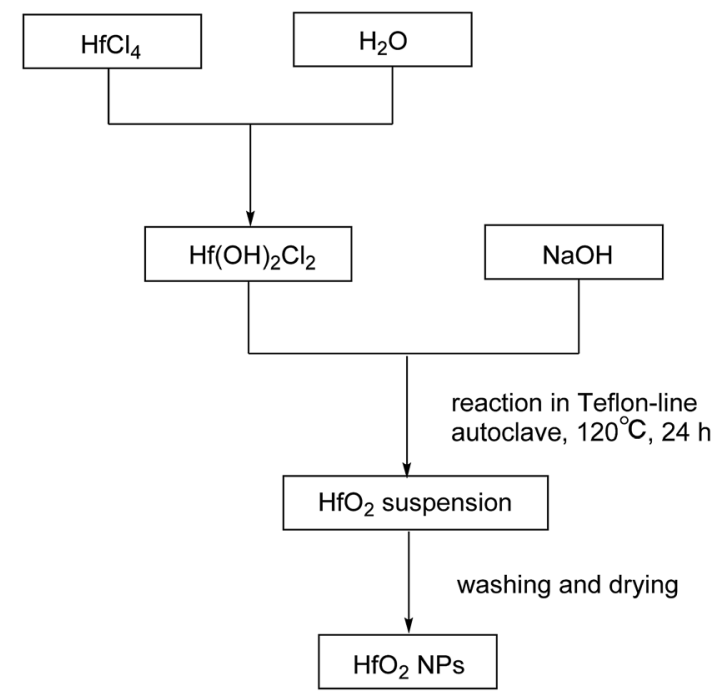

Scheme 1 Preparation of $\mathrm{HfO}_{2}$ NPS.

described as follows. To the solution prepared by dissolving $0.160 \mathrm{~g}$ of $\mathrm{HfCl}_{4}$ in $8.0 \mathrm{~mL}$ of de-ionized water, $10.0 \mathrm{~mL} \mathrm{NaOH}$ was added in order to make $0.1 \mathrm{M} \mathrm{NaOH}$ in aqueous phase, and $2.0 \mathrm{~mL}$ of $0.1 \mathrm{M}$ dodecylamine solution was mixed with the solution above by stirring for 2-3 h. Hereafter, the resulting mixture was transferred into a $100 \mathrm{~mL}$ Teflon-lined autoclave with inner diameter of $c a .4 .2 \mathrm{~cm}$ and maintained for $24 \mathrm{~h}$ after heated to $160{ }^{\circ} \mathrm{C}$. On the other hand, to obtain tetragonal $\mathrm{HfO}_{2}$ $\left(\mathrm{t}-\mathrm{HfO}_{2}\right)$ seeds, $5.0 \mathrm{~mL}$ of de-ionized water including $0.160 \mathrm{~g}$ of $\mathrm{HfCl}_{4}$ was added to $10 \mathrm{~mL}$ of $0.1 \mathrm{M}$ sodium dodecylbenzenesulfonate solution, along with agitation of 2-3 h. Then the mixture was transferred into a $100 \mathrm{~mL}$ Teflon-lined autoclave with addition of $5.0 \mathrm{~mL} \mathrm{NaOH}$ solution to make $3.0 \mathrm{M} \mathrm{NaOH}$ in aqueous phase. Afterwards, the autoclave was sealed and maintained for $24 \mathrm{~h}$ after heated to $100{ }^{\circ} \mathrm{C}$.

The products were purified by centrifugation for three cycles with alcohol and de-ionized water alternately after the autoclave was cooled down. Finally the precipitate was dried at $50{ }^{\circ} \mathrm{C}$ for $24 \mathrm{~h}$. The procedures are summarized in Scheme 2.

\section{Characterization}

The different morphologies and phases presenting in the solids were measured using X-ray powder diffraction (XRD, D/max, Rigaku, Tokyo, Japan) with $\mathrm{Cu}-\mathrm{K} \alpha$ radiation $(\lambda=1.5418 \AA)$ in a $2 \theta-\theta$ setup, the $2 \theta$ angle was scanned from 0 to $90^{\circ}$. JADE software (MDI JADE 7 Materials Data XRD Pattern Processing, Identification, and Quantification) was used to evaluate/analyze the XRD patterns. The JCPDS card no. 06-0318 and the JCPDS card no. 53-0550 were used as the XRD standard files of $\mathrm{m}-\mathrm{HfO}_{2}$ and $\mathrm{t}$ $\mathrm{HfO}_{2}$, respectively. The $\mathrm{pH}$ was measured by Sartorius PB-10.

Transmission electron microscopy (TEM) images were recorded with a JEOL JEM $2100 \mathrm{~F}$ transmission electronmicroscope, to analyze the product size and morphology. The samples used for TEM observations were prepared by dispersing the NPs in ethanol followed by ultrasonic vibration 


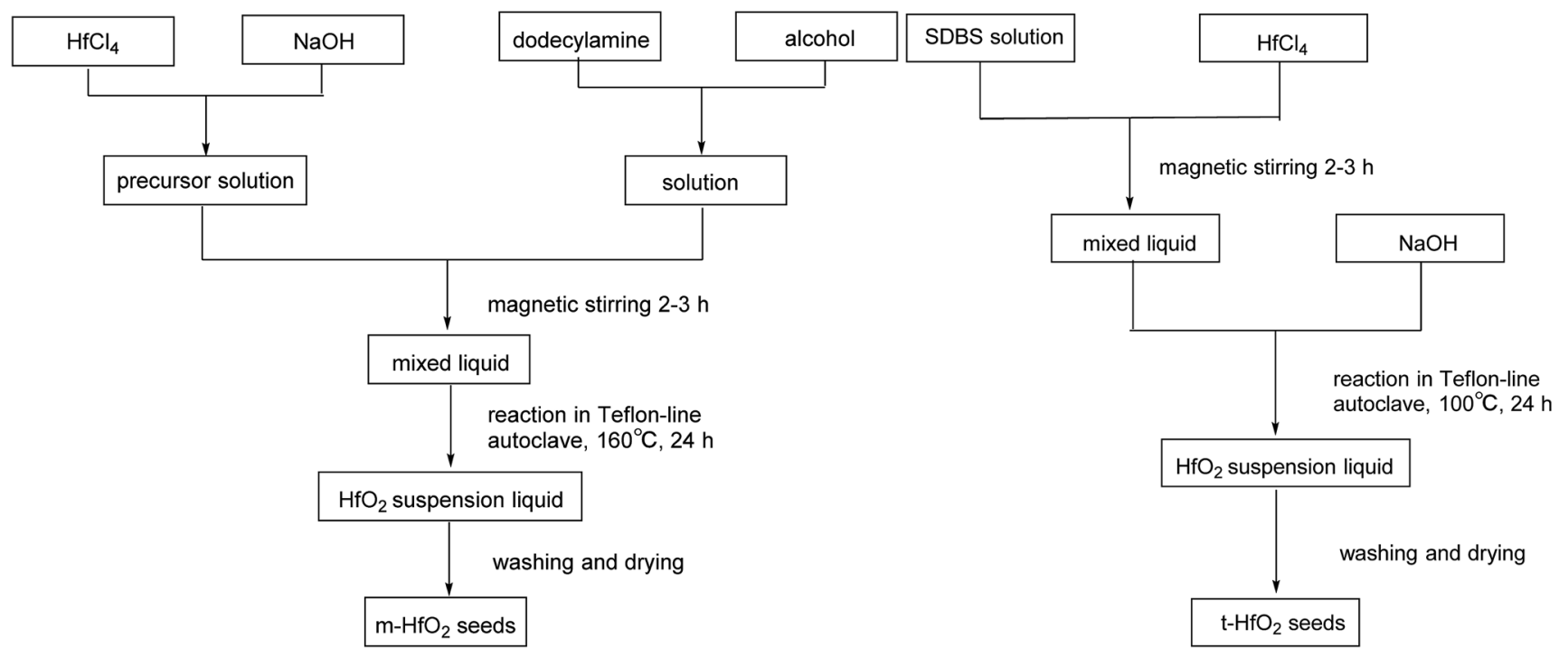

Scheme 2 Preparation of $\mathrm{HfO}_{2}$ seeds.

for $30 \mathrm{~min}$, and then placing a drop of this dispersion onto a copper grid before loading into the instrument.

\section{Results and discussion}

\section{Preparation of $\mathrm{HfO}_{2}$}

Fig. 1 shows the XRD spectra of both tetragonal hafnium oxide nanoparticles ( $\mathrm{t}-\mathrm{HfO}_{2}$ NPs) and monoclinic hafnium oxide nanoparticles ( $\mathrm{m}-\mathrm{HfO}_{2} \mathrm{NPs}$ ) prepared. The tetragonal phase of $\mathrm{HfO}_{2}$ was obtained under otherwise the standard conditions at $100{ }^{\circ} \mathrm{C}$, the monoclinic phase of $\mathrm{HfO}_{2}$ was obtained at $160{ }^{\circ} \mathrm{C}$. In Fig. 1(a), the major characteristics peaks found at $30.48^{\circ}$, $35.30^{\circ}, 50.68^{\circ}, 60.26^{\circ}$ on the $2 \theta$ scale correspond to the $\{111\}$, $\{200\},\{220\}$ and $\{311\}$ planes respectively, in good agreements

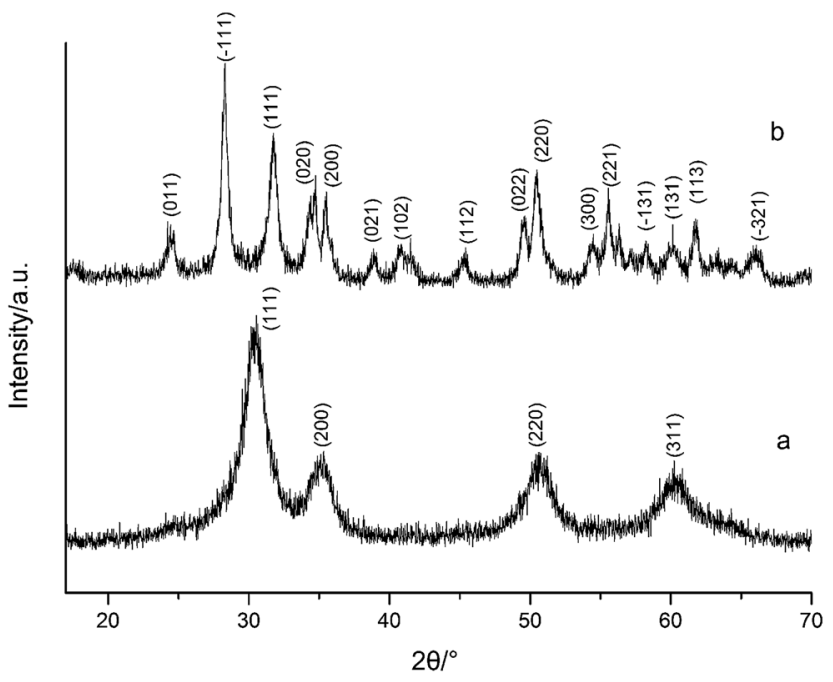

Fig. 1 XRD spectra of $\mathrm{HfO}_{2} \mathrm{NPs}$ prepared under otherwise the standard conditions (3.0 M NaOH and $24 \mathrm{~h}$ ) at different temperatures: (a) $100{ }^{\circ} \mathrm{C}$, (b) $160{ }^{\circ} \mathrm{C}$. with the standard PDF card of $\mathrm{t}-\mathrm{HfO}_{2}$ (JCPDS: no. 53-0550). The corresponding TEM image of near-spherical $\mathrm{t}-\mathrm{HfO}_{2}$ particles $(4.0 \mathrm{~nm})$ is presented in Fig. 2(a). In Fig. 1(b), the major characteristics peaks found at $24.64^{\circ}, 28.30^{\circ}, 31.76^{\circ}, 50.46^{\circ}$ on the $2 \theta$ scale correspond to the $\{011\},\{-111\},\{111\},\{220\}$ planes respectively, in good agreements with the standard PDF card of m- $\mathrm{HfO}_{2}$ (JCPDS: no. 06-0318). The corresponding TEM images of spindle-like m-HfO ${ }_{2}$ particles (ca. $\left.100 \mathrm{~nm} \times 50 \mathrm{~nm}\right)$ with a high aspect ratio is presented in Fig. 2(b). These nanoparticles are uniform, but some particles gather together.

The high-resolution TEM images shown in Fig. 2(a1) indicates high crystallinity of the structure, the $d$ spacing of lattice fringes of $0.25 \mathrm{~nm}$ and $0.29 \mathrm{~nm}$ are indexed to the (200) and (111) plane of $\mathrm{t}-\mathrm{HfO}_{2}$, respectively. In Fig. 2(b1), the $d$ spacing of lattice fringes of $0.28 \mathrm{~nm}$ and $0.32 \mathrm{~nm}$ are indexed to the (111) and $(-111)$ plane of $\mathrm{m}-\mathrm{HfO}_{2}$, respectively. All the $d$ spacing values are in close agreement with those from $\mathrm{t}-\mathrm{HfO}_{2}$ (JCPDS: no. 53-0550) and m-HfO (JCPDS: no. 06-0318).

\section{Effects of reaction conditions on the formation of $\mathrm{HfO}_{2}$ nanoparticles}

Reaction time. Fig. 3 and 4 present XRD spectra and TEM images of the products obtained with different aging time at $120{ }^{\circ} \mathrm{C}$ under the otherwise conditions. After aging for $3 \mathrm{~h}$, fine near-spherical particles of $4 \mathrm{~nm}$ in diameter were found in Fig. 4(a) and proved to be tetragonal phase by the XRD spectrum in Fig. 3. Shown as the white circle in Fig. 4(a), the particles grew and aggregated with the time going and the spindle-like particles began to appear after aging for $24 \mathrm{~h}$, as displayed in Fig. 4(b) in the white circle. Virtually, at this time the product has been a mixture of $\mathrm{t}-\mathrm{HfO}_{2}$ and $\mathrm{m}-\mathrm{HfO}_{2} \mathrm{NPs}$, as exhibited in the XRD spectrum in Fig. 3. After aging for $72 \mathrm{~h}$, from XRD spectrum in Fig. 3, the nanoparticles have been transformed into spindle-like $\mathrm{m}-\mathrm{HfO}_{2}(c a .120 \mathrm{~nm} \times 52 \mathrm{~nm})$ completely, as also being confirmed by that in Fig. $4(\mathrm{c})$. 


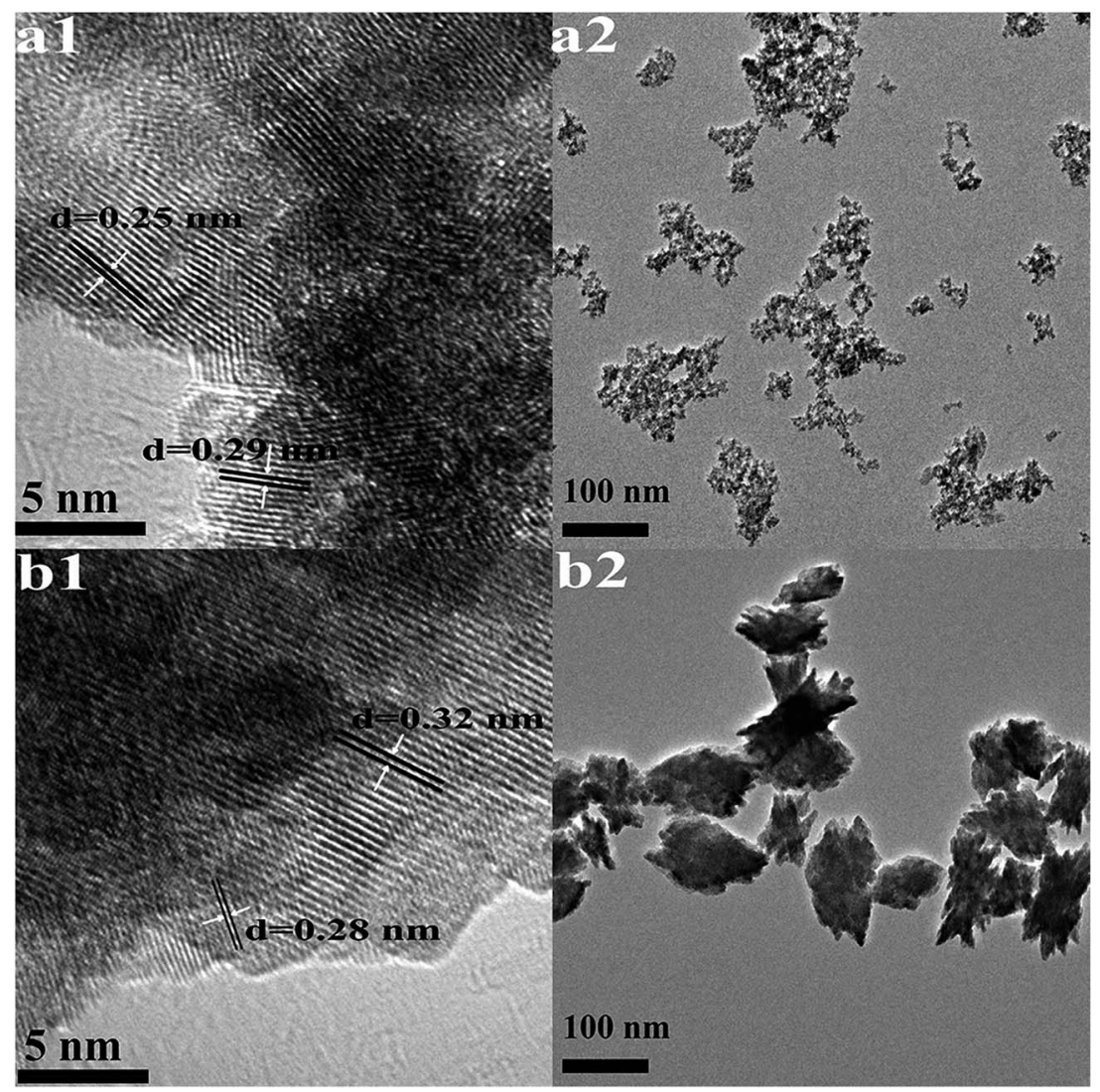

Fig. 2 HRTEM images (1) and TEM images (2) of $\mathrm{HfO}_{2}$ NPs prepared under otherwise the standard conditions (3.0 M NaOH and $\left.24 \mathrm{~h}\right)$ at different temperatures: (a) $100^{\circ} \mathrm{C}$, (b) $160^{\circ} \mathrm{C}$.

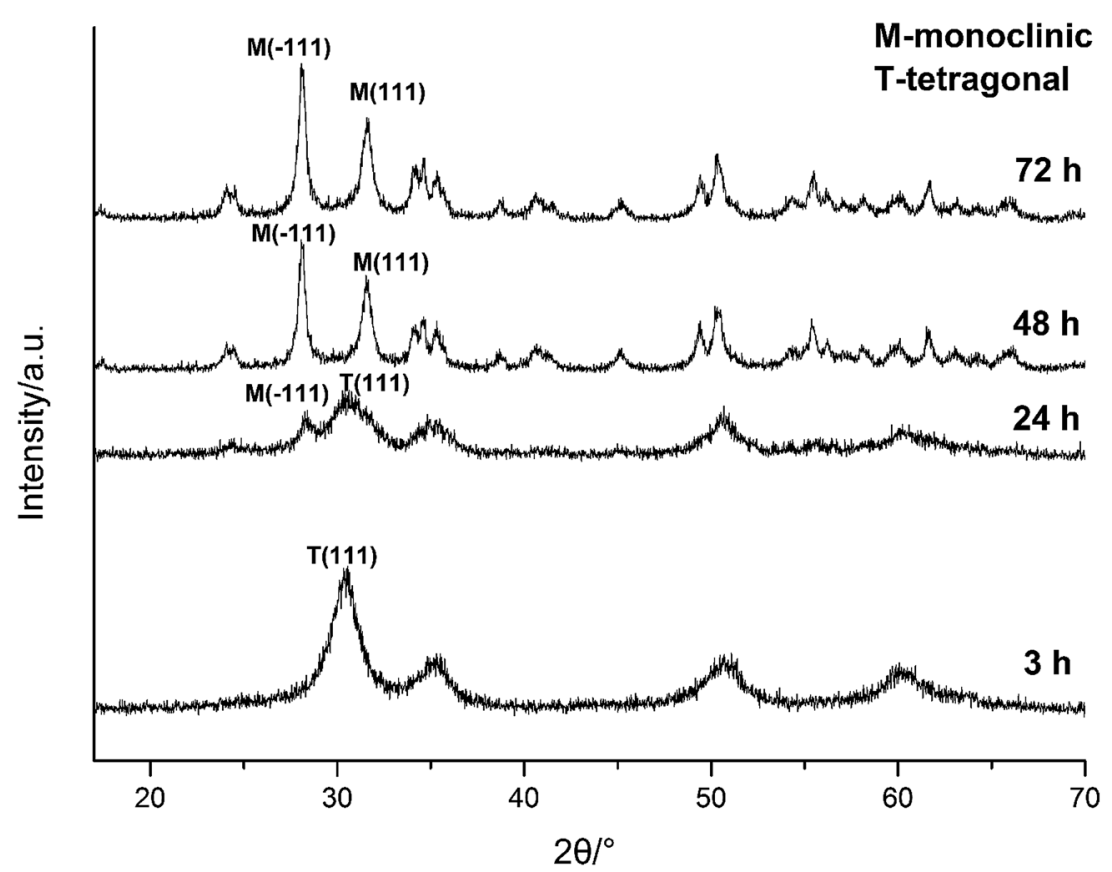

Fig. 3 XRD spectra of $\mathrm{HfO}_{2}$ NPs prepared under otherwise the standard conditions $\left(3.0 \mathrm{M} \mathrm{NaOH}\right.$ and $\left.120{ }^{\circ} \mathrm{C}\right)$ with different reaction time. 


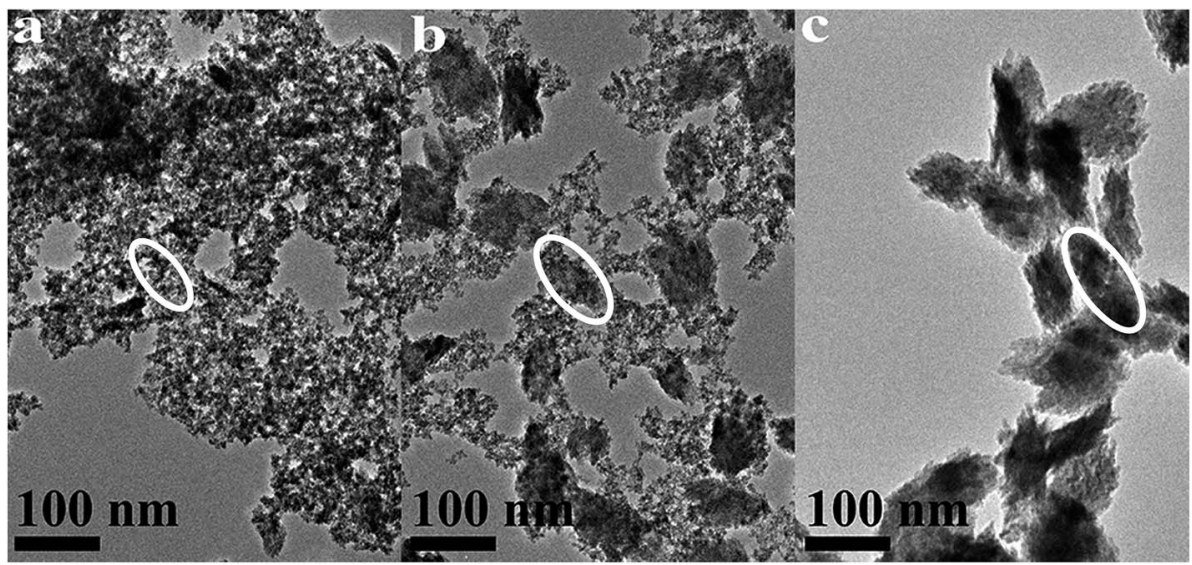

Fig. 4 TEM images of $\mathrm{HfO}_{2} \mathrm{NPs}$ prepared under otherwise the standard conditions $\left(3.0 \mathrm{M} \mathrm{NaOH}\right.$ and $120^{\circ} \mathrm{C}$ ) with different reaction time: (a) $3 \mathrm{~h}$, (b) $24 \mathrm{~h}$, (c) $72 \mathrm{~h}$.

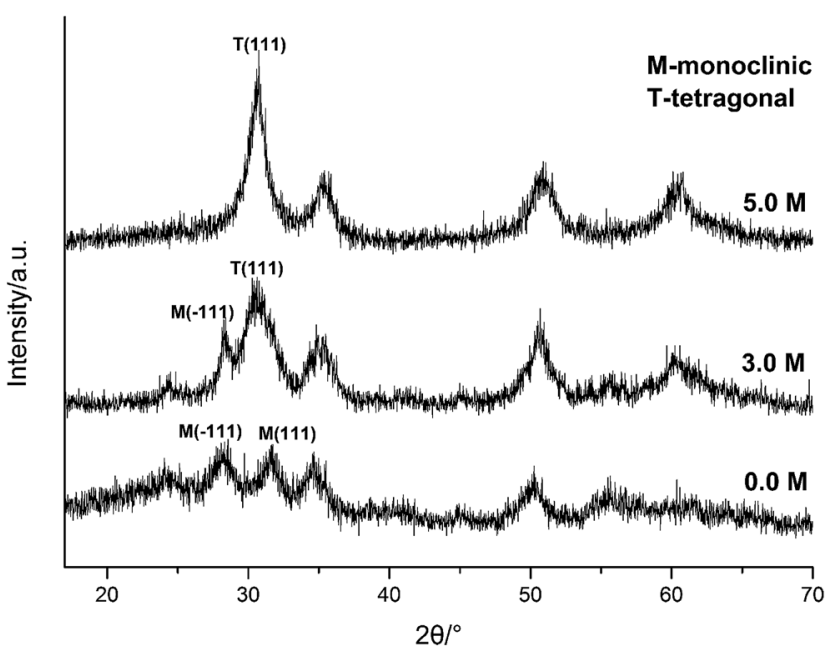

Fig. 5 XRD spectra of $\mathrm{HfO}_{2}$ NPs prepared under otherwise the standard conditions $\left(120{ }^{\circ} \mathrm{C}\right.$ and $24 \mathrm{~h}$ ) with different concentrations of $\mathrm{NaOH}$.
The above analysis reflected a phenomenon that the $\mathrm{m}-\mathrm{HfO}_{2}$ was not formed at beginning, but transformed from the $\mathrm{t}-\mathrm{HfO}_{2}$. In the early stage of reaction, the $\mathrm{t}-\mathrm{HfO}_{2} \mathrm{NPs}$ were firstly generated and then aggregated to form large secondary particles, which subsequently re-crystallized to produce m- $\mathrm{HfO}_{2} \mathrm{NPs}$. This fact indicates that $\mathrm{m}-\mathrm{HfO}_{2} \mathrm{NPs}$ probably have lower kinetic stability and higher thermodynamic stability in comparison to $\mathrm{t}-\mathrm{HfO}_{2}$ NPs.

Concentration of NaOH. XRD spectra in Fig. 5 show the diffraction peaks associated with $\mathrm{m}-\mathrm{HfO}_{2}$ and $\mathrm{t}-\mathrm{HfO}_{2}$ forms at different concentrations of $\mathrm{NaOH}$. The main peaks of $\mathrm{t}-\mathrm{HfO}_{2}$ appeared in the presence of $5.0 \mathrm{M} \mathrm{NaOH}(\mathrm{pH}=14.0)$, the corresponding TEM image of near-spherical $\mathrm{HfO}_{2}$ particles (3.0 $\mathrm{nm}$ ) is presented in Fig. 6(a). It was clearly observed that with decreasing concentration of $\mathrm{NaOH}$ to $3.0 \mathrm{M}(\mathrm{pH}=12.5)$, the low peaks in Fig. 5 and the spindle-like particles in Fig. 6(b) indicated the generation of $\mathrm{m}-\mathrm{HfO}_{2}$. Further decreasing led to the decline of peaks of $\mathrm{t}-\mathrm{HfO}_{2}$ and the enhancement of the peaks of $\mathrm{m}-\mathrm{HfO}_{2}$ in Fig. 5. Meantime, from Fig. 6(b), the mixture of the near-spherical and spindle-like $\mathrm{HfO}_{2}$ particles was found.

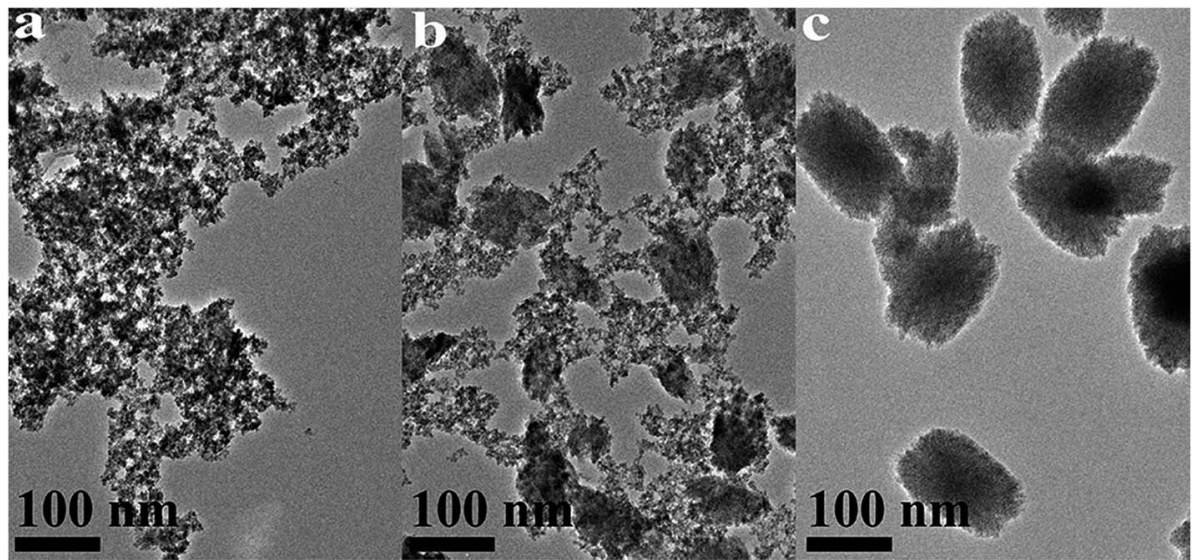

Fig. 6 TEM images of $\mathrm{HfO}_{2} \mathrm{NPs}$ prepared under otherwise the standard conditions $\left(120^{\circ} \mathrm{C}\right.$ and $\left.24 \mathrm{~h}\right)$ with different concentrations of $\mathrm{NaOH}$ : (a) $5.0 \mathrm{M}$, (b) $3.0 \mathrm{M}$, (c) $0 \mathrm{M}$. 
Decreasing $\mathrm{NaOH}$ concentration from $5.0 \mathrm{M}$ to 0 resulted in the formation of $\mathrm{m}-\mathrm{HfO}_{2}(c a .115 \mathrm{~nm} \times 70 \mathrm{~nm})$, indicated in Fig. 6(c).

Carefully considering the influence of $\mathrm{pH}$ or alkaline concentration on the formation of metal oxide from metal hydroxide, some metal hydro-complexes usually play a key role to the formation of metal oxide like $\mathrm{TiO}_{2}$ (ref. 24 and 25) and $\mathrm{ZrO}_{2}{ }^{22,26} \mathrm{Jia}$ et $a .^{27}$ suggested that the $\mathrm{pH}$ of the reaction mixture can control the dissociation rate of the precursor, which significantly affects the supply of metal ions or metal hydro-complexes in the reaction environment and thus the growth rate of the metal-oxide nanocrystals. For $\mathrm{HfO}_{2}$ particles, precursory complex $\mathrm{Hf}(\mathrm{OH})_{x}^{4-x}(x \geq 5)$, has been suggested ${ }^{28}$ from its influence on the particle size. On the other hand, A. Sahraneshin ${ }^{\mathbf{1 6}}$ proposed that the concentration of alkali can affect the growth of (111) plane of $\mathrm{HfO}_{2}$ which was unstable with higher surface energy. For the current synthesis of $\mathrm{HfO}_{2}$, with no doubt, the high concentration of $\mathrm{NaOH}$ is of benefit to the

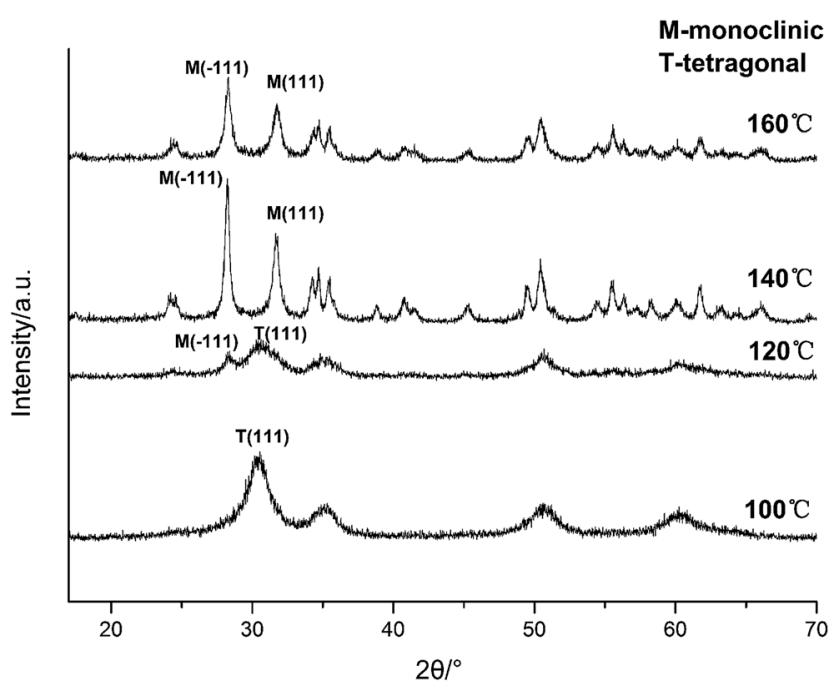

Fig. 7 XRD spectra of $\mathrm{HfO}_{2}$ NPs prepared under otherwise the standard conditions (3.0 M NaOH and $24 \mathrm{~h}$ ) at different temperatures. formation of primary $\mathrm{t}-\mathrm{HfO}_{2} \mathrm{NPs}$, this may be related to the effects of $\mathrm{NaOH}$ concentration on the precursor complex, which will be discussed in details in the latter section.

Reaction temperature. Undoubtedly, temperature is a key factor for the control of crystal forms. From the XRD spectra displayed in Fig. 7, the tetragonal phase of $\mathrm{HfO}_{2}(4.0 \mathrm{~nm})$ obtained at $100{ }^{\circ} \mathrm{C}$ under otherwise the standard conditions, the corresponding TEM image of near-spherical $\mathrm{t}-\mathrm{HfO}_{2}$ particles is presented in Fig. 8(a). The main peaks of $\mathrm{t}-\mathrm{HfO}_{2}$ became more obvious and the near-spherical particles began to accumulate as the temperature rose. Hereafter, the weak peak of $M(-111)$ of $\mathrm{m}-\mathrm{HfO}_{2}$ appeared at $120{ }^{\circ} \mathrm{C}$ indicated the trend of formation of $\mathrm{m}-\mathrm{HfO}_{2}$ as also revealed from that some tiny embryos of spindle-like m- $\mathrm{HfO}_{2} \mathrm{NPs}$ were discernible in Fig. 8(b). Indeed, all the nanocrystals were fully transformed into monoclinic phase in the temperature range of $140-160{ }^{\circ} \mathrm{C}$. The well crystallized monoclinic phase of $\mathrm{HfO}_{2}$ was obtained under the standard conditions at $160^{\circ} \mathrm{C}$, the corresponding TEM image of spindle-like $\mathrm{m}-\mathrm{HfO}_{2}$ particles $(c a .100 \mathrm{~nm} \times 50 \mathrm{~nm})$ is presented in Fig. 8(c).

Based on the XRD and TEM observation in Fig. 7 and 8, the reaction temperature is also the key factor that influences particle morphology under the fixed alkaline concentration and reaction time. It has been reported that with the increase of temperature, the particles are more likely to collide to form a large particle even with different form at enough high temperature. ${ }^{23-25}$ In this work, $\mathrm{t}-\mathrm{HfO}_{2} \mathrm{NPs}$ may collide mutually and transform to $\mathrm{m}-\mathrm{HfO}_{2} \mathrm{NPs}$ with the increase of temperature. Therefore, higher temperature, lower concentration of $\mathrm{NaOH}$, and longer reaction time are beneficial for the formation of monoclinic hafnium oxide nanoparticles.

Seeding. Fig. 9 exhibits XRD spectra of $\mathrm{HfO}_{2}$ nanocrystals prepared at $120{ }^{\circ} \mathrm{C}$ for $24 \mathrm{~h}$ with $3.0 \mathrm{M} \mathrm{NaOH}$ in the presence and the absence of $\mathrm{HfO}_{2}$ seeds. It was found that without seeds, both the main peaks of $\mathrm{m}-\mathrm{HfO}_{2}$ and $\mathrm{t}-\mathrm{HfO}_{2}$ appeared simultaneously, indicating that the product was a mixture of $\mathrm{t}-\mathrm{HfO}_{2}$ and $\mathrm{m}-\mathrm{HfO}_{2}$ particles, but in the presence of $\mathrm{t}-\mathrm{HfO}_{2}$ seeds, the main peaks were associated with $\mathrm{t}-\mathrm{HfO}_{2}$. Due to the addition of

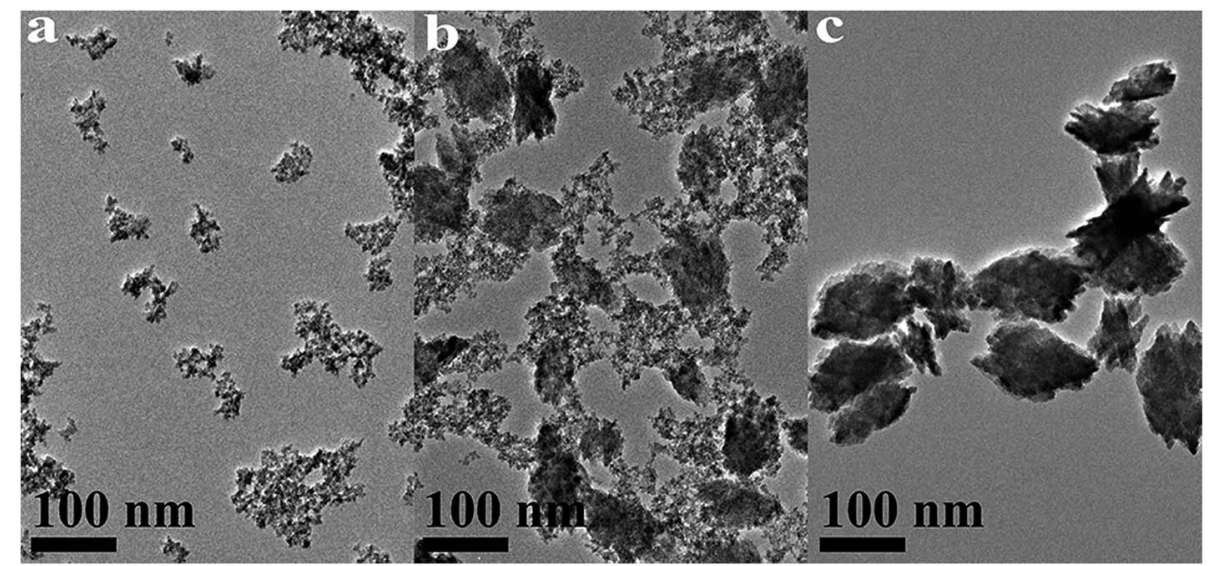

Fig. $8 \mathrm{TEM}$ images of $\mathrm{HfO}_{2} \mathrm{NPs}$ prepared under otherwise the standard conditions $\left(3.0 \mathrm{M} \mathrm{NaOH}\right.$ and 24 h) at different temperatures: (a) $100{ }^{\circ} \mathrm{C}$, (b) $120^{\circ} \mathrm{C}$, (c) $160^{\circ} \mathrm{C}$. 


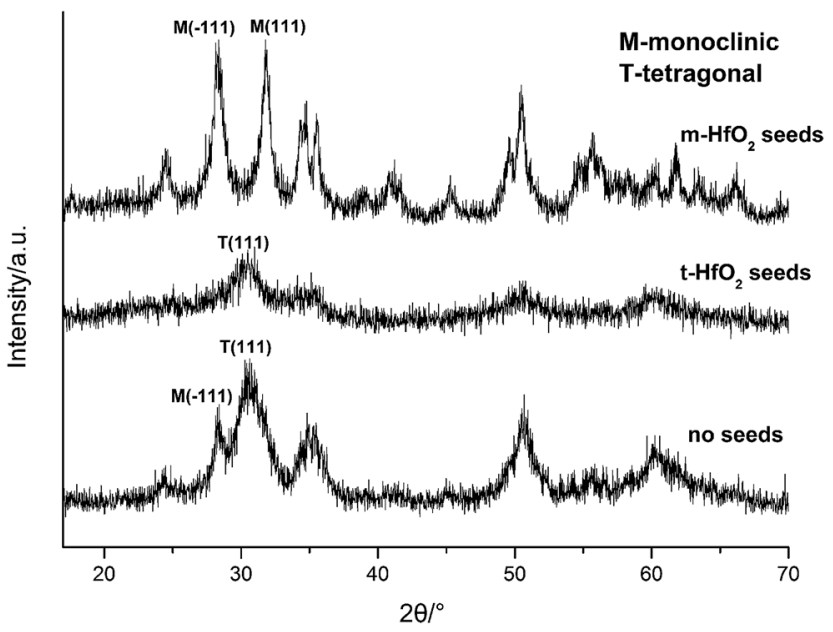

Fig. 9 XRD spectra of $\mathrm{HfO}_{2}$ NPs prepared with different seeds.

tetragonal seeds, the solute monomers deposited on the preexisting $\mathrm{t}-\mathrm{HfO}_{2}$ seeds and the size of the formed $\mathrm{t}-\mathrm{HfO}_{2} \mathrm{NPs}$ became larger and larger, inhibiting aggregation and the formation of secondary particles, and preventing the production of $\mathrm{m}-\mathrm{HfO}_{2} \mathrm{NPs}$. Obviously, the $\mathrm{t}-\mathrm{HfO}_{2}$ seeds promoted the growth of $\mathrm{t}-\mathrm{HfO}_{2}$ and inhibited the formation of $\mathrm{m}-\mathrm{HfO}_{2}$. This is a strong evidence for the fact that the growth and phase transformation of $\mathrm{t}-\mathrm{HfO}_{2} \mathrm{NPs}$ follow the non-aggregation and surface-deposition growth model..$^{23,29}$ The seeding technique is undoubtedly useful for preparing the t- $\mathrm{HfO}_{2} \mathrm{NPs}$, in spite of the difficulty to obtain the $\mathrm{t}-\mathrm{HfO}_{2} \mathrm{NPs}$. Interestingly, in the presence of $\mathrm{m}-\mathrm{HfO}_{2}$ seeds, the main peaks are associated with $\mathrm{m}-\mathrm{HfO}_{2}$. Due to the addition of monoclinic seeds, the solute monomers deposited on the pre-existing $\mathrm{m}-\mathrm{HfO}_{2}$ seeds, promoting the formation of $\mathrm{m}-\mathrm{HfO}_{2}$ and inhibiting the formation of $\mathrm{t}-\mathrm{HfO}_{2}$. In a word, the product was $\mathrm{t}-\mathrm{HfO}_{2}$ in the presence of $\mathrm{t}-\mathrm{HfO}_{2}$ seeds, and that was $\mathrm{m}-\mathrm{HfO}_{2}$ in the presence of $\mathrm{m}-\mathrm{HfO}_{2}$ seeds. That means, crystal form of seeds determines that of the product. It is a very interesting and significant result, as the saying goes "You must reap what you have sown".

\section{Formation mechanisms of $\mathrm{HfO}_{2}$ by a hydrothermal route}

Formation of $\mathbf{m}-\mathbf{H f O}_{2} \mathbf{N P s}$ from $\mathbf{t}-\mathbf{H f O}_{2} \mathbf{~ N P s}$. Three cell types of $\mathrm{HfO}_{2}$ forms are monoclinic (M), tetragonal (T) and cubic (C) as shown in Fig. 10. The coordination numbers of $\mathrm{Hf}^{4+}$ both in cubic and tetragonal cells are 8 to form $\mathrm{Hf}_{-} \mathrm{O}_{8}{ }^{2-}$ structure, while that of monoclinic cell is 7 to form $\mathrm{Hf}-\mathrm{O}_{7}{ }^{2-}$ structure. The structure of $\mathrm{m}-\mathrm{HfO}_{2}$ can be viewed that the $\mathrm{t}-\mathrm{HfO}_{2}$ deflects a certain angle, along the $\beta$ axis. Usually, structures with coordination number of 8 have better geometric symmetry and are easier to form, but monoclinic cell with coordination number of 7 is stable thermodynamically indeed. Under normal temperatures, the $\mathrm{m}-\mathrm{HfO}_{2}$ is the most stable, which is a reason for obtaining t- $\mathrm{HfO}_{2} \mathrm{NPs}$ with difficulty.

In terms of structures of $\mathrm{t}-\mathrm{HfO}_{2}$ and $\mathrm{m}-\mathrm{HfO}_{2}, \mathrm{t}-\mathrm{HfO}_{2}$ has better geometric symmetry compared with $\mathrm{m}-\mathrm{HfO}_{2}$, and a rule of thumb is that better symmetry products usually have good kinetic stability and are easy to be produced preferentially. Generally, the occurrence of any reaction or variance is comprehensively selected or controlled by both factors of thermodynamics and kinetics, and the reaction in the initial stage is controlled mainly by factor of kinetics.

In our experiment, $\mathrm{t}-\mathrm{HfO}_{2} \mathrm{NPs}$ are easier to form compared with $\mathrm{m}-\mathrm{HfO}_{2} \mathrm{NPs}$ and then the $\mathrm{t}-\mathrm{HfO}_{2}$ gradually transforms to $\mathrm{m}-\mathrm{HfO}_{2}$ with temperature rising or time going. In our previous work, ${ }^{28}$ the m- $\mathrm{HfO}_{2}$ NPs were obtained at $160{ }^{\circ} \mathrm{C}$ with $3.0 \mathrm{M}$ $\mathrm{NaOH}$ for $24 \mathrm{~h}$, but in the early stage of this reaction $(1 \mathrm{~h}$ and 3 $\mathrm{h}$ ), the products were $\mathrm{t}-\mathrm{HfO}_{2}$ NPs. It can be deduced that generally $\mathrm{t}-\mathrm{HfO}_{2}$ is produced originally and $\mathrm{m}-\mathrm{HfO}_{2}$ will be

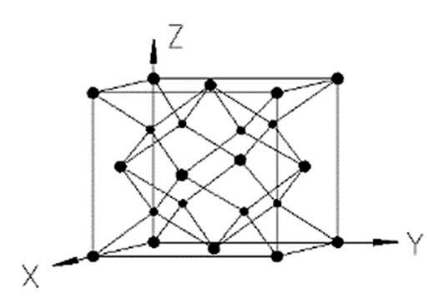

cubic cell

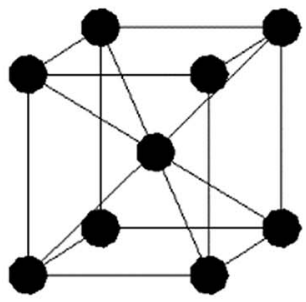

cubic cell

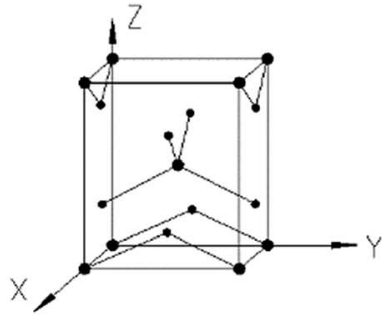

tetragonal cell

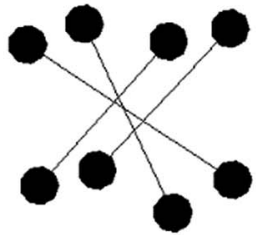

tetragonal cell

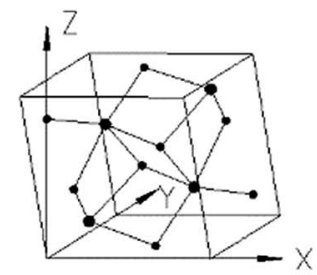

monoclinic cell

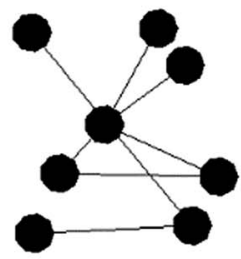

monoclinic cell

Fig. 10 Structures of different $\mathrm{HfO}_{2}$ crystal cells. 
obtained by transformation from t- $\mathrm{HfO}_{2}$. We have mentioned that under adequate temperature and concentration of $\mathrm{NaOH}$, the products were a mixture of $\mathrm{t}-\mathrm{HfO}_{2}$ and $\mathrm{m}-\mathrm{HfO}_{2}$. Moreover, based on the influence of temperature and concentration of $\mathrm{NaOH}$ on products, it is confirmed that $\mathrm{t}-\mathrm{HfO}_{2}$ is produced originally and $\mathrm{m}-\mathrm{HfO}_{2}$ is obtained by transformation from t$\mathrm{HfO}_{2}$. Therefore, it can be concluded that $\mathrm{t}-\mathrm{HfO}_{2}$ is stable kinetically and $\mathrm{m}-\mathrm{HfO}_{2}$ is stable thermodynamically.

To further confirm it above, the aging time of the reaction at $100{ }^{\circ} \mathrm{C}$ with $3.0 \mathrm{M} \mathrm{NaOH}$ was extended from $24 \mathrm{~h}$ to $168 \mathrm{~h}$, the XRD spectra are shown in Fig. 11. Obviously, the products were mainly t- $\mathrm{HfO}_{2}$ NPs after $24 \mathrm{~h}$, but after $168 \mathrm{~h}$, the products were mainly $\mathrm{m}-\mathrm{HfO}_{2} \mathrm{NPs}$. Passage of time led to the weakening of peaks of $\mathrm{t}-\mathrm{HfO}_{2}$ and the appearance of the peaks of $\mathrm{m}-\mathrm{HfO}_{2}$ in Fig. 11. After $168 \mathrm{~h}$, it was surprising to see that all of $\mathrm{t}-\mathrm{HfO}_{2} \mathrm{NPs}$ was transformed to $\mathrm{m}-\mathrm{HfO}_{2}$ NPs. The result offers a clear proof that the $\mathrm{m}-\mathrm{HfO}_{2}$ is stable thermodynamically and the $\mathrm{m}-\mathrm{HfO}_{2}$ is commonly transformed from $\mathrm{t}-\mathrm{HfO}_{2}$.

The formation of $\mathrm{t}-\mathrm{HfO}_{2}$ with high geometric symmetry becomes more possible in alkaline circumstance. Contrarily, the formation of $\mathrm{m}-\mathrm{HfO}_{2}$ is probably inhibited when the concentration of $\mathrm{NaOH}$ in solution is enough high. It is reasonable that high concentration of $\mathrm{NaOH}$ can inhibit transformation from t- $\mathrm{HfO}_{2}$ to $\mathrm{m}-\mathrm{HfO}_{2}$, because high concentration of $\mathrm{NaOH}$ can offer more coordinating oxygen ions and then more oxygen ions are beneficial for formation of oxides with high coordination number. These oxygen ions increase the possibility of the occurrence of the structure with high coordination number and high symmetry, and reduce that of the occurrence of distortion, leading to the formation of $\mathrm{t}-\mathrm{HfO}_{2}$ NPs. In a word, high concentration of $\mathrm{NaOH}$ is beneficial for formation of $\mathrm{t}-\mathrm{HfO}_{2}$ and inhibits the formation of $\mathrm{m}-\mathrm{HfO}_{2}$, this has been confirmed by our previous report. ${ }^{28}$ More interestingly, it is also found that with the increased concentration of $\mathrm{NaOH}$, the size of the obtained $\mathrm{t}-\mathrm{HfO}_{2}$ decreased in the concentrated $\mathrm{NaOH}$ aqueous solution.

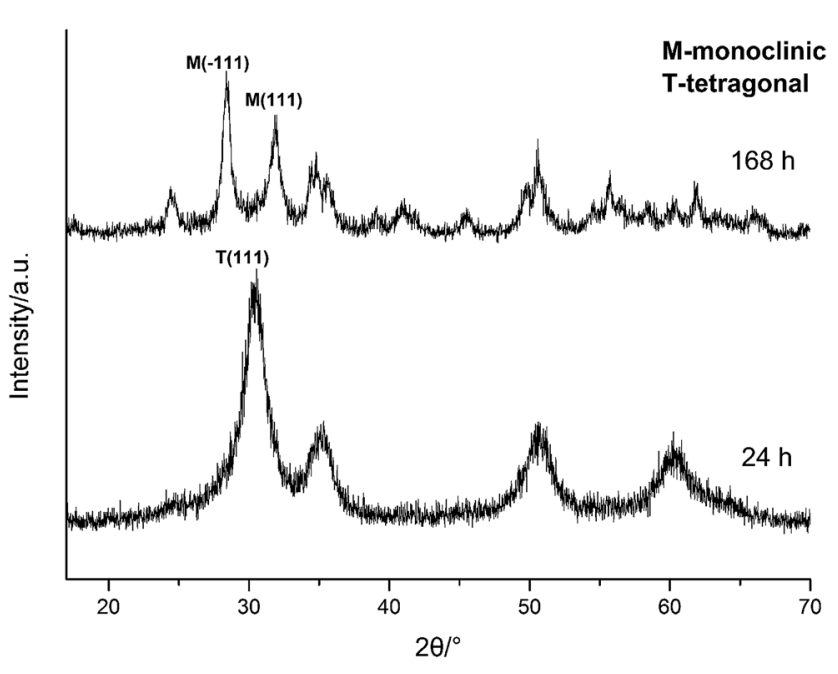

Fig. 11 XRD spectra of $\mathrm{HfO}_{2}$ NPs prepared under otherwise the standard conditions $\left(3.0 \mathrm{M} \mathrm{NaOH}\right.$ and $\left.100{ }^{\circ} \mathrm{C}\right)$ with different reaction time.
On the other hand, temperature is often an important factor to determine the reaction direction and even to determine the crystal form of products. In this work, it has been found that the high temperature is beneficial for the formation of $\mathrm{m}-\mathrm{HfO}_{2}$. It could be caused by particles annealing and the difference in the structures of the two forms of $\mathrm{HfO}_{2}$. Generally, large crystals can be formed by annealing of small crystals, along with the change in the crystal forms in some cases. Therefore, with the rise in temperature, the transformation of $\mathrm{t}-\mathrm{HfO}_{2}$ to $\mathrm{m}-\mathrm{HfO}_{2}$ can be explained in terms of the collision and the distortion in the process of the annealing. It has been reported that with the increase of temperature, the particles are more likely to collide, resulting in the reduction of coordination number, thus forming a large particle. ${ }^{23-25} \mathrm{As}$ a result, these small $\mathrm{t}-\mathrm{HfO}_{2}$ crystals were transformed to large $\mathrm{m}-\mathrm{HfO}_{2}$ crystals due to the reduction of coordination number.

Formation process of $\mathrm{HfO}_{2}$ NPs with and without seeds. Generally, the meta-stable $\mathrm{t}-\mathrm{HfO}_{2} \mathrm{NPs}$ are formed firstly due to their high formation rate. Then, with the passage of time, the particles change from $\mathrm{t}-\mathrm{HfO}_{2}$ to $\mathrm{m}-\mathrm{HfO}_{2}$ with thermodynamic stability. Based on the significant analyses in the former parts, the formation process of $\mathrm{HfO}_{2}$ by the hydrothermal route is illustrated as follows.

In Fig. 12, after accomplishment of reaction between hafnium hydroxide chlorides and $\mathrm{OH}^{-}$in the water, the precursory complex $\mathrm{Hf}(\mathrm{OH})_{x}^{4-x}(x \geq 5)$ gather and react in the water. Through nucleation of solute monomers without seeds, the meta-stable $\mathrm{t}-\mathrm{HfO}_{2}$ NPs appear. Under appropriate conditions, the product is a mixture of $\mathrm{t}-\mathrm{HfO}_{2} \mathrm{NPs}$ and $\mathrm{m}-\mathrm{HfO}_{2} \mathrm{NPs}$ because some t- $\mathrm{HfO}_{2} \mathrm{NPs}$ transform to m- $\mathrm{HfO}_{2} \mathrm{NPs}$. However, the main product is $\mathrm{m}-\mathrm{HfO}_{2} \mathrm{NPs}$ under higher temperature and lower alkali, whereas the product under the opposite conditions is $\mathrm{t}-\mathrm{HfO}_{2} \mathrm{NPs}$. In other words, higher temperature and lower alkali concentration are beneficial for the formation of $\mathrm{m}-\mathrm{HfO}_{2}$. For better control of crystal forms, the seeds are added. When the adequate $\mathrm{t}-\mathrm{HfO}_{2}$ seeds exist, the solute monomers will deposit on $\mathrm{t}-\mathrm{HfO}_{2}$ seeds and the size of formed $\mathrm{t}-\mathrm{HfO}_{2} \mathrm{NPs}$ become larger and larger, inhibiting aggregation and the formation of secondary particles, and then preventing the production of $\mathrm{m}-\mathrm{HfO}_{2} \mathrm{NPs}$. Obviously, the t- $\mathrm{HfO}_{2}$ seeds promote the growth of $\mathrm{t}-\mathrm{HfO}_{2}$ and inhibit the formation of $\mathrm{m}-\mathrm{HfO}_{2}$. In the other hand, when the m- $\mathrm{HfO}_{2}$ seeds are added, the solute monomers will deposit on the pre-existing $\mathrm{m}-\mathrm{HfO}_{2}$ seeds, promoting the formation of $\mathrm{m}-\mathrm{HfO}_{2}$ and inhibiting the formation of $\mathrm{t}-\mathrm{HfO}_{2}$. In a word, the product is $\mathrm{t}-\mathrm{HfO}_{2}$ in the presence of $\mathrm{t}-\mathrm{HfO}_{2}$ seeds, and that is $\mathrm{m}-\mathrm{HfO}_{2}$ in the presence of $\mathrm{m}-\mathrm{HfO}_{2}$ seeds.

For nucleation, the overall Gibbs free energy change, ${ }^{30} \Delta G$, should be considered. $\Delta G$, is the sum of the free energy due to the formation of the cluster and that due to the new surface created. In Fig. 13(b), $\Delta G$ has a positive maximum at a critical size, $r^{*}$. This maximum free energy change is the activation energy for nucleation. Nuclei or clusters larger than the critical size will further decrease their free energy for growth and become stable ones that grow to form particles.

Usually, it is somewhat hard to make $\Delta G<0$ in the absence of seeds. However, once the seeds preformed stably are added, 


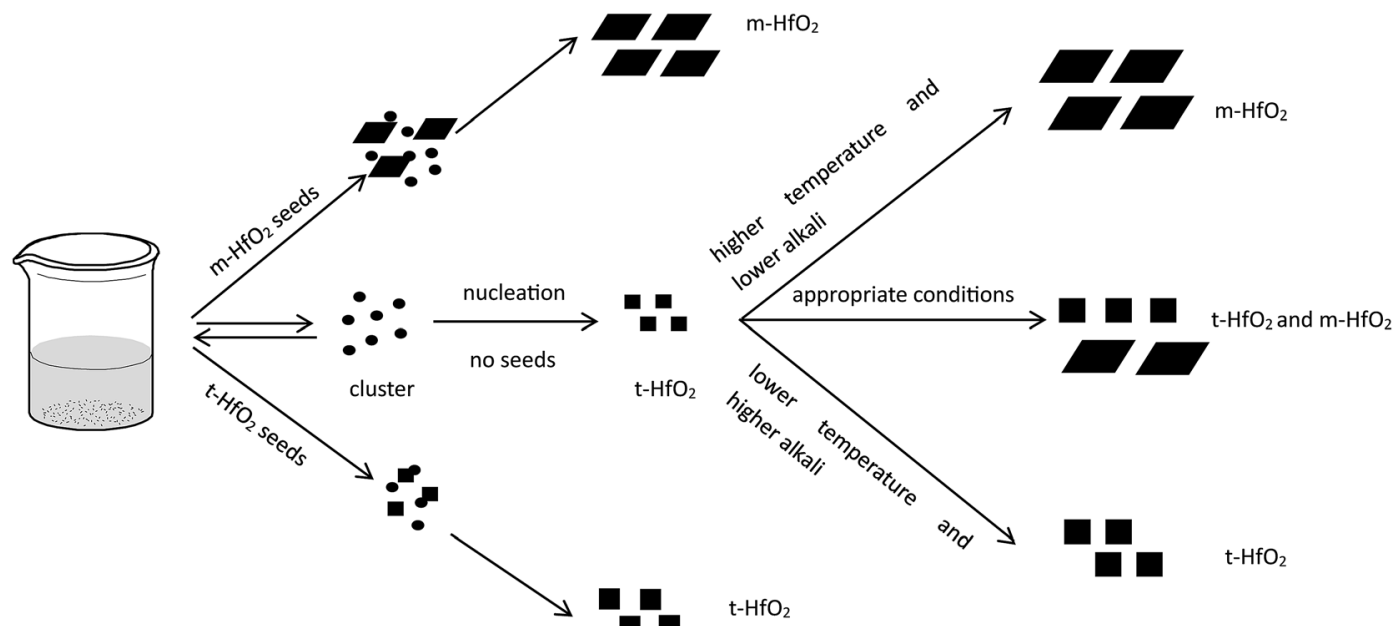

Fig. 12 Formation and transformation processes of $\mathrm{HfO}_{2} \mathrm{NPs}$ with and without seeds.

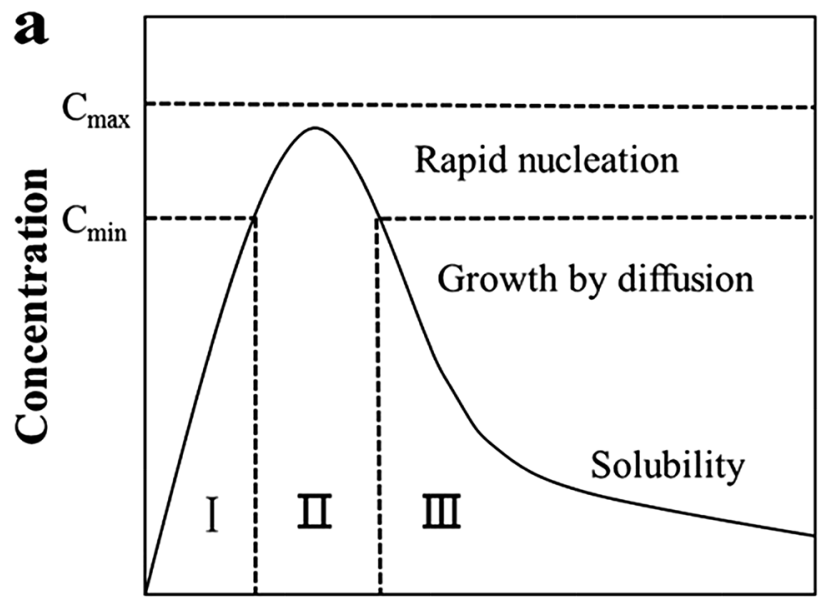

Time

b

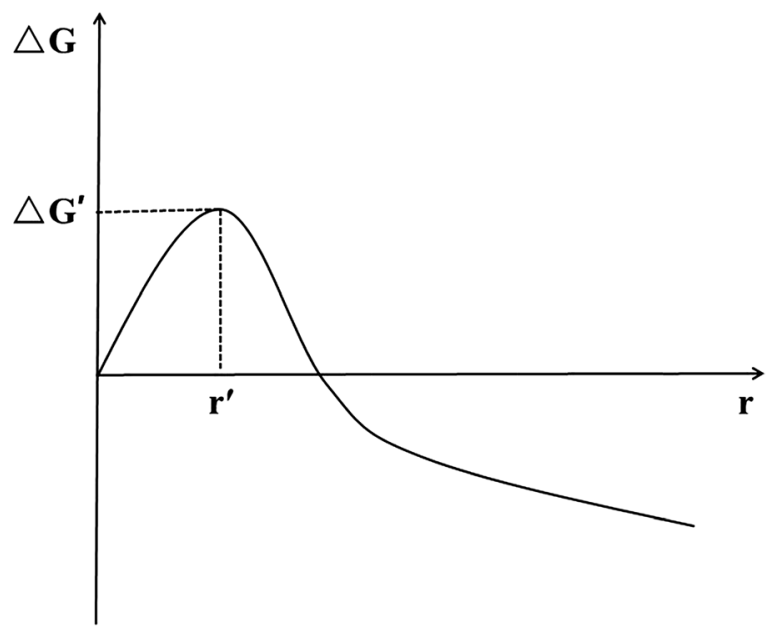

Fig. 13 (a) LaMer model schematic diagram ${ }^{32}$ and (b) illustration of the overall free energy $\Delta G$ as a function of the growth particle size $r^{30}$ spontaneous nucleation is inhibited, and then they grow by deposition of monomers on their surfaces to become large particles. At this time, the overall free energy change $\Delta G$, could be much lowered even to less than 0 . That means, the formation process of stable solute clusters or particles is skipped (Fig. 13(a)) and the reaction is accelerated. Therefore, the resulting final nanoparticles are smaller in size and more evenly dispersed. Undoubtedly, the seeding technique is useful for the systematic control of crystal form and for the study of the growth and nucleation mechanisms. ${ }^{31}$

Reaction and precursor species for formation of $\mathrm{HfO}_{2} \mathbf{N P s}$. Generally, in aqueous solution, $\mathrm{pH}$ affects the concentration of hydro-complexes. By analysis and calculation of the equilibrium constants involving hydrolysis of hafnium ions from D. Rai's report, ${ }^{33}$ the changes of mole fractions of the four main hydro-complex species with $\mathrm{pH}$ are summarized and shown in Fig. 14. In our work, we measured the yield of $\mathrm{t}-\mathrm{HfO}_{2} \mathrm{NPs}$ under different $\mathrm{pH}$. These $\mathrm{t}-\mathrm{HfO}_{2} \mathrm{NPs}$ were prepared at $100{ }^{\circ} \mathrm{C}$

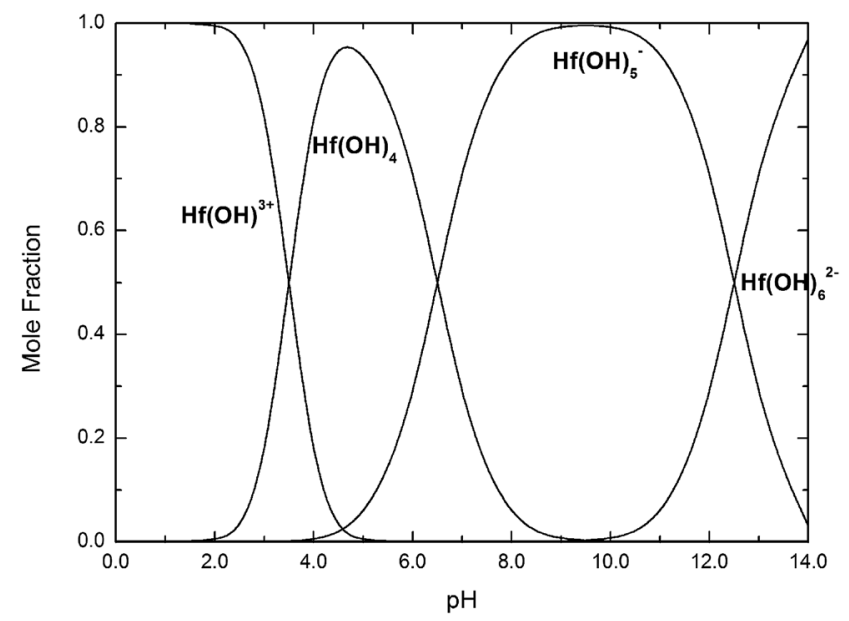

Fig. 14 Mole fractions of $\mathrm{Hf}(\mathrm{OH})^{3+}, \mathrm{Hf}(\mathrm{OH})_{4}, \mathrm{Hf}(\mathrm{OH})_{5}{ }^{-}, \mathrm{Hf}(\mathrm{OH})_{6}{ }^{2-}$ complexes as a function of $\mathrm{pH}$ at $25^{\circ} \mathrm{C}$. 
a

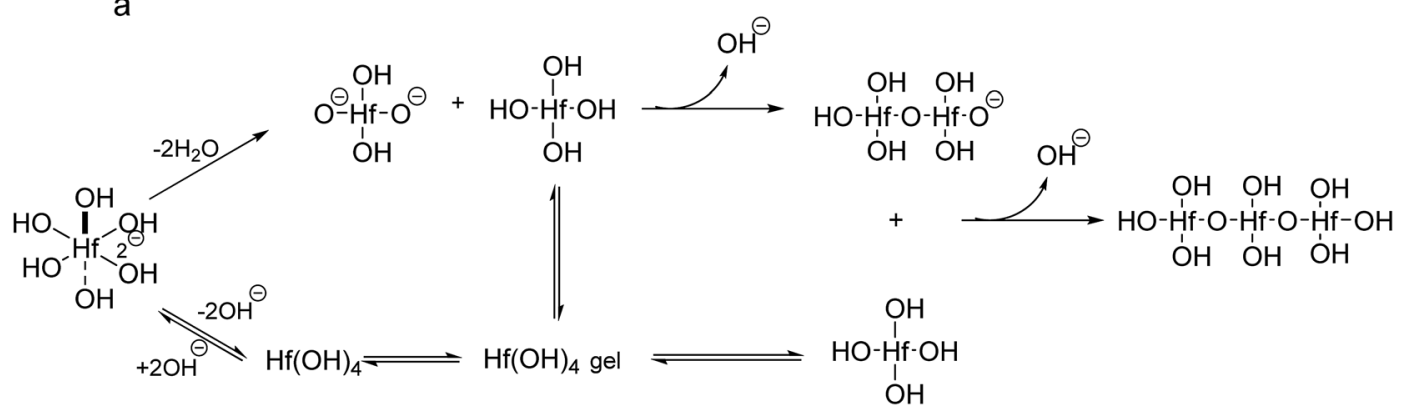

b

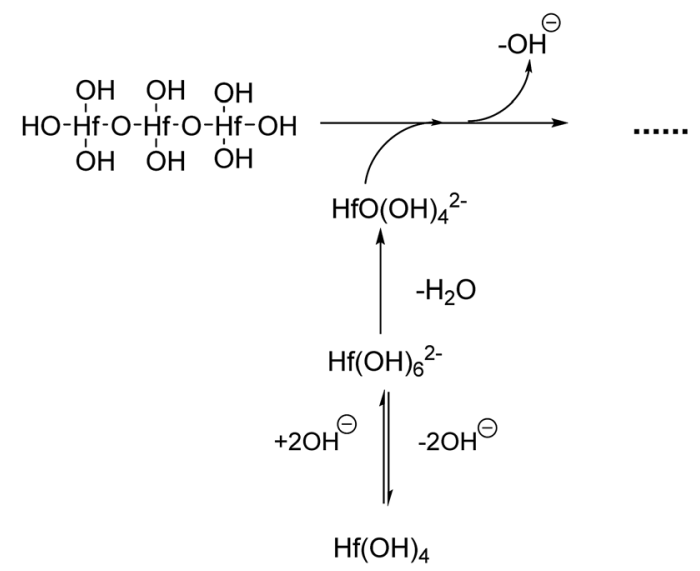

Fig. 15 Formation of $\mathrm{HfO}_{2}$ from $\mathrm{Hf}(\mathrm{OH})_{6}{ }^{2-}$ and $\mathrm{Hf}(\mathrm{OH})_{4}$.

with 3.0 M NaOH for $24 \mathrm{~h}$. Respectively, when pH was 11.5, 12.5 and 13.5 , the yields of $\mathrm{t}-\mathrm{HfO}_{2}$ were $70.8 \%, 82.1 \%$ and $90.5 \%$, respectively. Obviously, the yield of $\mathrm{t}-\mathrm{HfO}_{2}$ increases with the increase of $\mathrm{pH}$ in this $\mathrm{pH}$ range. In our previous study, the high concentration of $\mathrm{NaOH}$ not only promotes the formation of $\mathrm{t}-\mathrm{HfO}_{2}$, but also declines particle size of $\mathrm{t}-\mathrm{HfO}_{2}$. Clearly, the $\mathrm{pH}$ dependence on the nucleation rate of $\mathrm{t}-\mathrm{HfO}_{2}$ reveals that some specific complex is responsible for the nucleation of $\mathrm{t}-\mathrm{HfO}_{2}$ as a precursor intermediate. The increase of the formation rate, or nucleation rate, with the increase of $\mathrm{pH}$ from 10.0 to 14.0 may be closely related to the increase in the equilibrium concentration of $\mathrm{Hf}(\mathrm{OH})_{6}{ }^{2-}$ in Fig. 14. The high concentration of precursors usually results in the rapid nucleation, leading to the production of more nuclei, and then decreasing the particle size. Therefore, the $\mathrm{Hf}(\mathrm{OH})_{6}{ }^{2-}$ species is assigned to the precursory complex to form $\mathrm{t}-\mathrm{HfO}_{2}$ in the hydrothermal system.

If we take into account that the overall reaction for the transformation from $\mathrm{Hf}(\mathrm{OH})_{4}$ gel to $\mathrm{HfO}_{2}$ sol is $\mathrm{Hf}(\mathrm{OH})_{4} \rightarrow$ $\mathrm{HfO}_{2}+2 \mathrm{H}_{2} \mathrm{O}$, the precursory complex must only be a catalyst or an intermediate, and thus $\mathrm{Hf}(\mathrm{OH})_{4}$ complex, constantly furnished from the $\mathrm{Hf}(\mathrm{OH})_{4}$ gel with the progress of the reaction, may also contribute to the poly-condensation reaction in the formation of $\mathrm{HfO}_{2}$ particles. The transformation is similar to production of $\mathrm{TiO}_{2}$ from $\mathrm{Ti}(\mathrm{OH})_{4},{ }^{24} \mathrm{CeO}_{2}$ from $\mathrm{Ce}(\mathrm{OH})_{4}$ (ref. 34) and $\mathrm{ZrO}_{2}$ from $\mathrm{Zr}(\mathrm{OH})_{4}{ }^{22,35}$ The following elementary processes may be involved in the overall reaction shown in Fig. 15(a and b), deduced from those of $\mathrm{TiO}_{2}$ (ref. 24) and $\mathrm{CeO}_{2} \cdot{ }^{34}$

\section{Conclusions}

The $\mathrm{HfO}_{2}$ nanoparticles (NPs) were prepared successfully by a hydrothermal route. The phase transformation of $\mathrm{HfO}_{2}$ occurs through changing the reaction temperature, the concentration of $\mathrm{NaOH}$, aging time and crystal form of seeds. XRD spectra and TEM images revealed the near-spherical particles belonged to tetragonal $\mathrm{HfO}_{2}\left(\mathrm{t}-\mathrm{HfO}_{2}\right)$, and the spindle-like particles belonged to monoclinic $\mathrm{HfO}_{2}\left(\mathrm{~m}-\mathrm{HfO}_{2}\right)$. Based on the kinetic and thermodynamic analyses, it can be induced that higher temperature, lower concentration of $\mathrm{NaOH}$ and longer reaction time are beneficial for the formation of $\mathrm{m}-\mathrm{HfO}_{2}$ nanoparticles. Moreover, it is confirmed that $\mathrm{t}-$ $\mathrm{HfO}_{2}$ generally produces originally and $\mathrm{m}-\mathrm{HfO}_{2}$ is obtained by transformation from $\mathrm{t}-\mathrm{HfO}_{2}$.

In the standard conditions at $120^{\circ} \mathrm{C}$ with $3.0 \mathrm{M} \mathrm{NaOH}$ for $24 \mathrm{~h}$, the product is a mixture of $\mathrm{t}-\mathrm{HfO}_{2}$ and $\mathrm{m}-\mathrm{HfO}_{2} \mathrm{NPs}$ in the absence of seeds. When $\mathrm{m}-\mathrm{HfO}_{2}$ seeds are added, the resultant is pure $\mathrm{m}-\mathrm{HfO}_{2} \mathrm{NPs}$, while $\mathrm{t}-\mathrm{HfO}_{2}$ seeds are added, under the same conditions the particles are pure t- $\mathrm{HfO}_{2} \mathrm{NPs}$, proving the non-aggregation growth of nanoparticles. Not only the crystal form of $\mathrm{HfO}_{2}$ can be well controlled, but also the particles size can be altered. The addition of $\mathrm{HfO}_{2}$ seeds decreases the size of 
nanoparticles. In the presence of seeds, the declined activated energy for the reaction is due to the decrease of $\Delta G$, resulting from the skipping of spontaneous nucleation stage, and then causing separation of nucleation from growth.

The effect of solution $\mathrm{pH}$ on the formation of $\mathrm{HfO}_{2}$ NPs was learned by the analysis above. Meantime, the high concentration of $\mathrm{NaOH}$ promoted the formation of $\mathrm{t}-\mathrm{HfO}_{2} \mathrm{NPs}$. Therefore, the hydro-complex $\mathrm{Hf}(\mathrm{OH})_{6}{ }^{2-}$ has been confirmed as the precursor complex to form $\mathrm{HfO}_{2}$ particles.

\section{Acknowledgements}

The authors gratefully acknowledge the Foundation of Shanghai Municipal Commission of Economy and Informatization (15XI-1-28).

\section{Notes and references}

1 C. A. Mirkin, R. L. Letsinger, R. C. Mucic and J. J. Storhoff, Nature, 1996, 382, 607-609.

2 D. L. Feldheim and C. D. Keating, Chem. Soc. Rev., 1998, 27, 1-12.

3 S. Saito, Science, 1997, 278, 77-78.

4 J. Robertson, Rep. Prog. Phys., 2006, 69, 327-396.

5 J. De Roo, K. De Keukeleere, J. Feys, P. Lommens, Z. Hens and I. Van Driessche, J. Nanopart. Res., 2013, 15, 1778.

6 G. D. Wilk, R. M. Wallace and J. M. Anthony, J. Appl. Phys., 2001, 89, 5243-5275.

7 J. Molina, R. Ortega, W. Calleja, P. Rosales, C. Zuniga and A. Torres, Mater. Sci. Eng., B, 2012, 177, 1501-1508.

8 S. A. Eliziario, L. S. Cavalcante, J. C. Sczancoski, P. S. Pizani, J. A. Varela, J. W. M. Espinosa and E. Longo, Nanoscale Res. Lett., 2009, 4, 1371-1379.

9 R. Terki, G. Bertrand, H. Aourag and C. Coddet, Mater. Lett., 2008, 62, 1484-1486.

10 V. Jayaraman, G. Bhavesh, S. Chinnathambi, S. Ganesan and P. Aruna, Mater. Express, 2014, 4, 375-383.

11 W. E. Buhro and V. L. Colvin, Nat. Mater., 2003, 2, 138-139.

12 H. B. Yao, M. R. Gao and S. H. Yu, Nanoscale, 2010, 2, 323334.

13 E. Tirosh and G. Markovich, Adv. Mater., 2007, 19, 26082612.

14 J. S. Quintero-Garcia, B. A. Puente-Urbina, L. A. GarciaCerda, O. S. Rodriguez-Fernandez and E. MendozaMendoza, Mater. Lett., 2015, 159, 520-524.
15 A. Ramadoss, K. Krishnamoorthy and S. J. Kim, Mater. Lett., 2012, 75, 215-217.

16 A. Sahraneshin, S. Asahina, T. Togashi, V. Singh, S. Takami, D. Hojo, T. Arita, K. Minami and T. Adschiri, Cryst. Growth Des., 2012, 12, 5219-5226.

17 P. E. Meskin, F. Y. Sharikov, V. K. Ivanov, B. R. Churagulov and Y. D. Tretyakov, Mater. Chem. Phys., 2007, 104, 439-443.

18 E. Montes, P. Ceron, T. R. Montalvo, J. Guzman, M. GarciaHipolito, A. B. Soto-Guzman, R. Garcia-Salcedo and C. Falcony, Appl. Radiat. Isot., 2014, 83, 196-199.

19 L. Xiang, Y. P. Yin and Y. Jin, J. Mater. Sci., 2002, 37, 349-352. 20 H. B. Yin, Y. Wada, T. Kitamura, S. Kambe, S. Murasawa, H. Mori, T. Sakata and S. Yanagida, J. Mater. Chem., 2001, 11, 1694-1703.

21 Y. Q. Zheng, E. R. Shi, Z. Z. Chen, W. J. Li and X. F. Hu, J. Mater. Chem., 2001, 11, 1547-1551.

22 T. T. Shi, Y. T. Cai, L. Liu and X. P. Zhou, Colloids Surf., A, 2015, 469, 83-92.

23 T. Sugimoto, X. P. Zhou and A. Muramatsu, J. Colloid Interface Sci., 2003, 259, 43-52.

24 T. Sugimoto, X. P. Zhou and A. Muramatsu, J. Colloid Interface Sci., 2002, 252, 339-346.

25 T. Sugimoto and X. P. Zhou, J. Colloid Interface Sci., 2002, 252, 347-353.

26 L. Liu, J. C. Xue and X. P. Zhou, Nanosci. Nanotechnol. Lett., 2014, 6, 346-352.

27 C. Jia, Y. Cheng, F. Bao, D. Chen and Y. Wang, J. Cryst. Growth, 2006, 294, 353-357.

28 J. J. Qi and X. P. Zhou, Colloids Surf., A, 2015, 487, 26-34.

29 X. P. Zhou, S. S. Li, X. L. Chen, Q. Zhu, Z. Q. Wang and J. Zhang, J. Nanosci. Nanotechnol., 2008, 8, 1392-1397.

30 I. V. Markov, Crystal growth for beginners: fundamentals of nucleation, crystal growth and epitaxy, World Scientific, 2003.

31 S. Taotao, C. Yutian, L. Li and Z. Xingping, Colloids Surf., A, 2015, 469, 83-92.

32 C. Burda, X. Chen, R. Narayanan and M. A. El-Sayed, Chem. Rev., 2005, 105, 1025-1102.

33 D. Rai, Y. X. Xia, N. J. Hess, D. M. Strachan and B. P. McGrail, J. Solution Chem., 2001, 30, 949-967.

34 X. S. Zheng, L. Liu and X. P. Zhou, Colloid J., 2014, 76, 558563.

35 R. R. Piticescu, C. Monty, D. Taloi, A. Motoc and S. Axinte, J. Eur. Ceram. Soc., 2001, 21, 2057-2060. 